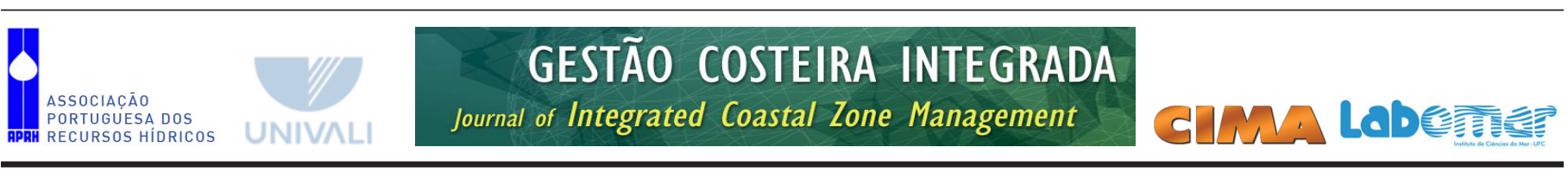

http://www.aprh.pt/rgci/pdf/rgci-494_Antunes.pdf | DOI:10.5894/rgci494

\title{
Hydrogeochemistry assessment of volcanic lakes in the Flores Island Protected Areas (Azores, Portugal) *
}

\author{
Monitorização bidrogeoquímica de lagos vulcânicos das áreas protegidas na \\ ilha das Flores (Açores, Portugal)
}

\author{
P. Antunes ${ }^{\circledR, 1,2} \&$ F.C. Rodrigues ${ }^{2}$
}

|

\begin{abstract}
Azorean lakes represent strategic freshwater resources and are subject to unprecedented levels of anthropogenic disturbance. The Flores Island lakes contribute 5\% of the total water volume of aquatic systems in the Azores and are an important habitat for freshwater species. Sampled lakes are located inside maars structures. Lake Negra, with a depth of $115 \mathrm{~m}$, is the deepest lake. The lakes water is cold, with thermal stratification observed during sampling campaigns. pH has varied from 5.43 to 9.94 and they are very dilute waters. Aquatic systems waters are fresh and of the $\mathrm{Na}-\mathrm{Cl}$ and $\mathrm{Na}-\mathrm{Ca}-\mathrm{HCO} 3$ types. It is possible to identify three major processes that control the hydrogeochemical evolution of the lake water studied here: (1) a marine sea salt input due to atmospheric transportation and deposition; (2) the hydrolysis of volcanic rock and; (3) a contribution of mineral water flowing through the rim of the crater. Aquatic systems have no direct interaction with seepage of magmatic fluids, a common process in Azores lakes. The highest decline in lake water quality is related to anthropogenic activities.
\end{abstract}

Keywords: Volcanic lakes, hydrogeochemistry, eutrophication, Flores Island (Azores).

\section{RESUMO}

Os lagos vulcânicos dos Açores são reservas estratégicas de água doce que estão sujeitos a distúrbios no seu equilibrio natural devido a factores antropogénicos. Os lagos dos Açores representam 5\% do total do volume de água doce que os sistemas lacustres dos Açores encerram, constituindo um importante habitat para as espécies que habitam ou fazem uso destes recursos naturais. Os lagos estudados localizam-se no interior de maars e a Lagoa Negra, com uma profundidade de $115 m$ é o lago mais profundo dos Açores., Durante as campanhas de amostragem, os lagos apresentaram estratificação de origem térmica, o pH varia entre valores ligeiramente ácidos a básicos, a água tem baixa mineralização e é fria. Os sistemas aquáticos estudados possuem água doce de tipologia cloretada sódica e as amostras de água dos sistemas de maior volume demonstram um enriquecimento em bicarbonato e cálcio. Foi possivel identificar 3 processos que controlam o quimismo da água dos lagos: (1) a entrada de sais de origem marinha através do acarreio atmosférico; (2) a entrada em solução de elementos químicos através da interação água-rocha e (3) a entrada de água ligeiramente mineralizada na Lagoa Comprida através de duas nascentes localizadas no flanco SE desta lagoa. Os sistemas lacustres estudados apresentam resultados que indicam não haver interação de fluidos de origem magmática, processo que ocorre noutros lagos dos Açores. A degradação da qualidade da água dos sistemas lacustres estudados está relacionada com o processo de eutrofização.

Palavras chave: Lagos vulcânicos, hidrogeoquímica, eutrofização, Ilha das Flores (Açores).

@ - Corresponding author: <paullusunes@gmail.com>

1 - UMASS, Department of Geosciences, Amberst, MA 01002-9297, USA

2 - CITA-A, Universidade dos Açores, Angra do Heroísmo, Portugal. 


\section{INTRODUCTION}

Lakes are generally regarded as strategic sources of fresh water. The increase in world population and improved living standards as well as the need for more resources has recently contributed to a growing demand for fresh water resources. Freshwater habitats are under unprecedented levels of pressure by humans, not only to satisfy people's basic needs, but also to satisfy agricultural and industrial demands, which has led to the subsequent deterioration of freshwater quality worldwide. In the Azores archipelago, three lakes are utilized for human water supplies. The island's geomorphology and climate have provided the Azores with significant quantities of groundwater and lakes. The Azores archipelago contains a total of 88 lakes (Porteiro, 2000), occupying a surface area of approximately $0.5 \%$ of the archipelago. The Azorean lakes gained important attention after the eutrophication process arose in a significant number of the archipelago's aquatic systems (UNL, 1991; Gonçalves, 1997; INOVA, 1999). The Azores archipelago is a remote region comprising nine small islands. With limited resources and a fragile environment, agriculture and livestock are the main economic activities creating environmental challenges. Nutrient emissions from agricultural activities are the main source of nutrient loads into lakes, and eutrophication has been increasing because of agricultural and livestock activities. Volcanic lakes may also receive magmatic fluids inputs (Delmelle \& Bernard, 2000; Varekamp et al., 2000; Antunes, 2009), which are extremely concentrated and acidic (Rowe et al., 1992; Christenson, 2000; Delmelle \& Bernard, 2000; Varekamp, 2008) and contributes to the degradation of the water quality of groundwater and surface water in volcanic areas. The quality of ground and surface water is a sensitive environmental topic (Saunders et al., 2002; Simeonov et al., 2003). Lake water quality is a measure of the physical, chemical, and biological health of an aquatic system and it is difficult to define a single standard threshold for water quality beyond which the system will be degraded (Karr, 1993; Brabec et al., 2002).

Protection of natural areas is a partial solution to habitat degradation, but specific protections of groundwater and surface water are rarely implemented worldwide (Hockings et al., 2006; Saunders et al., 2002; Hockings, 2003). Freshwater is commonly protected when lakes are integrated incidentally in natural reserves. However, inclusion in protected areas does not guarantee protection (Moyle et al., 1998; Saunders et al., 2002). The Flores lakes chosen for the present study, Lakes Negra, Comprida, Funda and Rasa, located in the Natural Reserves, are classified by the Regional Legislative Decree Law no 15/2007/A, June 25 and created through the Regional Legislative Decree Law 15/87/A, July 24 (Fig. 1). Lake Negra and Comprida are located in the designated Natural Reserve of Morro Alto e Pico da Sé and Lake Funda and Rasa are located in the Natural Reserve of Caldeiras Funda e Rasa.

The main goals for these protected areas are to establish mechanisms of conservation and preservation, and ecosystem management of biodiversity, natural resources and landscapes. The Natural Reserves are humid zones located at high altitude in the designated Central Plateau. The area is characterized as a turf zone occupied by different species of Sphagnum and the endemic Azores Juniper (juniperus brevifolia), important to the hydrological equilibrium of the island. The island of Flores is located in a bird migration corridor and the humid zones are an important habitat for these birds to feed and rest. The aim of this work is to perform a hydrogeochemical survey of aquatic systems located in a Natural Reserve system in Flores, and identify and describe the main mechanisms that control the water chemistry. It also aims to improve the understanding of mechanisms of water degradation and contribute chemical data to data base that will allow for a temporal scale study in the future. With the present study we intend to contribute to a better hydrogeochemical understanding of the dynamic of aquatic systems, primarily identifying if volcanic fluid contamination exist and how it affects the lakes water quality in order to improve the planning and management plans for protected areas in small islands. Biological processes will be taken in consideration, but they are not the focus of the study.

\subsection{Geological setting}

The Azores Islands represent the emerged portion of the Azores Plateau, limited by the bathymetric of $2000 \mathrm{~m}$ (Fig 2). The Azores are located at the junction between the North American, Eurasian and African lithospheric plates (in a complex geodynamic setting reflected by several tectonic structures, which explains the high level of seismicity and volcanic activity). The Mid-Atlantic Ridge (MAR) crosses the archipelago between the islands of Flores (West Group) and Faial (Central Group) (Krause \& Watkins, 1970; Laughton \& Whitmarsh, 1974; Steinmetz et al., 1976; Searle, 1980; Forjaz, 1983; Lourenço et al., 1998). Flores Island lies west of the Mid-Atlantic Ridge (MAR) on the American Plate.

The Azores archipelago is located in the North Atlantic Ocean, between the latitudes of $37^{\circ}-40^{\circ} \mathrm{N}$ and the longitudes of $25^{\circ}-31^{\circ} \mathrm{W}$ and can be divided in three groups according to the geographical distribution of the nine inhabited islands (Fig. 2). Flores Island is located in the Western group and has an area of $143 \mathrm{~km}^{2}$ with a population approximately 4000 inhabitants. The Central Plateau, located between $500 \mathrm{~m}$ and $915 \mathrm{~m}$ high, represents $40 \%$ of Flores inland plain area (Azevedo, 1998).

Lake Negra and Comprida are located in the central western part of the Central Plateau and Lake Funda and Rasa are located in the southernwest part of the Central Complex (Fig. 1). The lakes are emplaced within Maar structures (except Rasa lake) produced by violent phreatomagmatic eruption. Morriseau (1987) classified Lake Rasa as emplaced in a cinder cone. Although, there is no evidence of a crater and the lake could have resulted from a tectonic depression. Lake Comprida shows an elliptical shape since it is hosted within coalescent hydromagmatic eruptions. Table 1 presents other relevant physical characteristics of the studied lakes.

\subsection{Climate}

The archipelago position influences Azorean weather. The Azores are located in the middle North Atlantic Ocean 


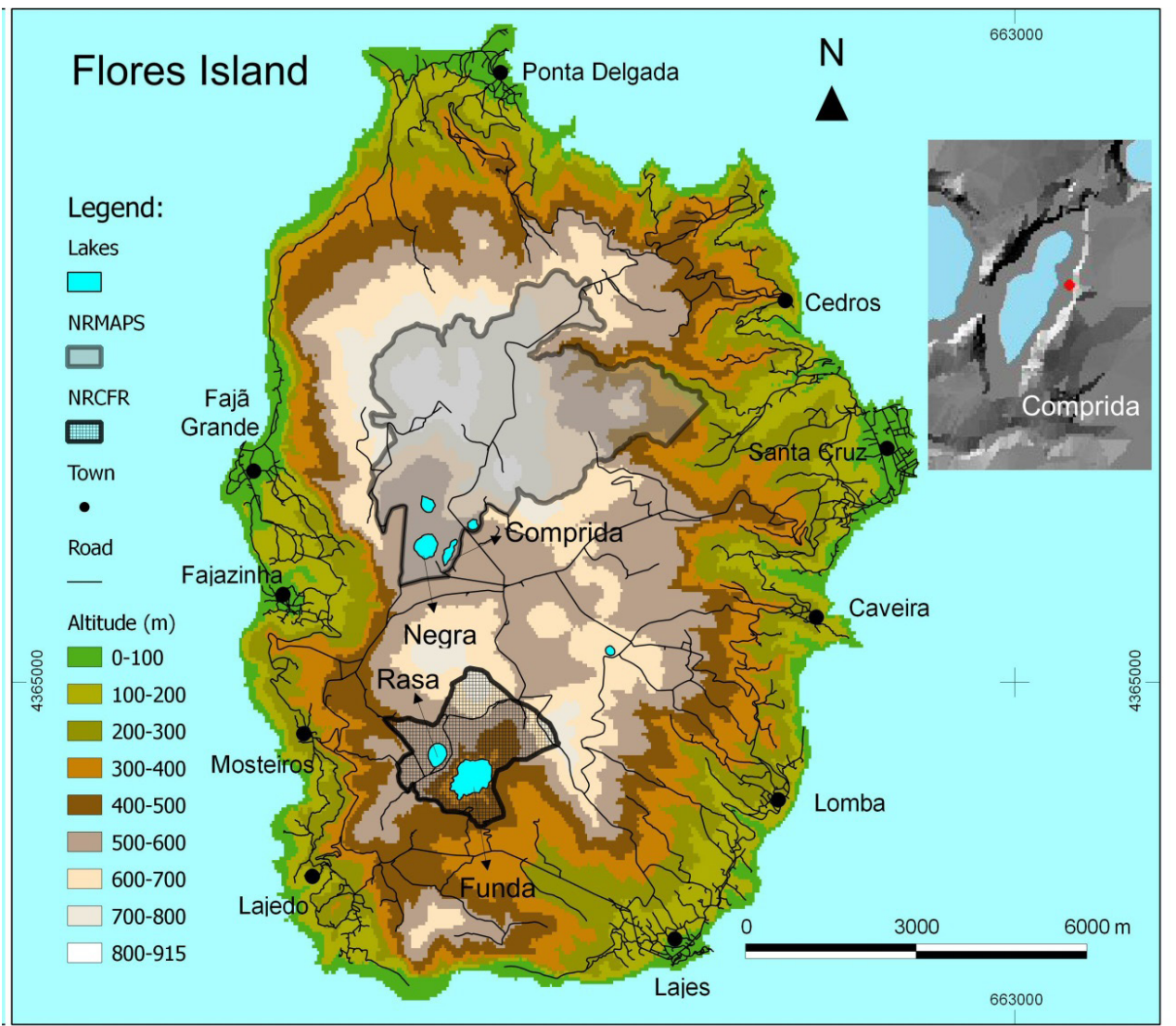

Figure 1. Map showing Flores Island, the location of the study lakes and the limit of natural areas. NRMAPS - Natural Reserve of Morro Alto and Pico da Sé, NRCFR - Natural Reserve of Caldeiras Funda and Rasa, • spring I and II location in Lake Comprida rim (sketch is not scaled).

Figura 1. Localização dos lagos estudados e dos limites das Reservas Naturais na ilha das Flores. NRMAPS - Reserva Natural do Morro Alto e Pico da Sé; NRCFR - Reserva Natural das Caldeiras Funda and Rasa, • localização das nascentes na margem da Lagoa Comprida (esquema não está à escala).

under the influence of subtropical high pressure (Azores anticyclone) resulting in a humid subtropical climate. It is possible to distinguish two seasons: (1) a relative humid season with high precipitation between September and March, and with steady wind due to the frequent crossing of low pressure systems associated with the polar front, and (2) a dry season during the other months controlled by the influence of Azorean anticyclone (Bettencourt, 1979; Azevedo, 1996). The climate is largely influenced by the Gulf warm current and the ocean that has an important role in air temperatures (Agostinho, 1938; Miranda et al., 2006). The temperature variation with $100 \mathrm{~m}$ altitude is approximatly $0.6^{\circ} \mathrm{C}$ and a $2.4 \%$ increase of humidity saturation (Agostinho 1938; Bettencourt, 1979). The average annual rainfall in the Azores is $15851 / \mathrm{m}^{2}$ and evapotranspiration is $597 \mathrm{l} / \mathrm{m}^{2}$.

Flores weather is influenced by the orography of the island with lower temperatures throughout the year (average $17.8^{\circ} \mathrm{C}$ ) and an average annual precipitation of $1430 \mathrm{~mm}$ (Bettencourt, 1979).

\section{SAMPLING AND ANALYTICAL METHODS}

Water from Flores Lakes were sampled in July 2005 and July 2007. Negra Lake was sample once in May 2006. Rasa Lake was sampled in July 2005 and July 2007. Comprida and Funda Lakes were sampled in July 2005, May 2006 and July 2007. Samples were taken along the vertical water column at defined locations during the two campaigns. Water samples were collected at different intervals from a pneumatic boat with a VanDorne sampler. During the sample campaigns, $\mathrm{pH}$, temperature, electrical conductivity and dissolved oxygen (DO) concentration were recorded with portable digital meters. In the field, dissolved $\mathrm{CO}_{2}$ and alkalinity were determined by titration, and samples were filtered $(0.2 \mu \mathrm{m})$ and stored in HDPE bottles. Samples for cation analyses were acidified with suprapur nitric acid. In the laboratory, major cation concentrations were determined by atomic-absorption spectrometry, while $\mathrm{Si}$ and $\mathrm{Fe}$ were analyzed by ICP-MS at Activation Laboratories, Canada. The major anion concentrations were determined by ion chromatography. 


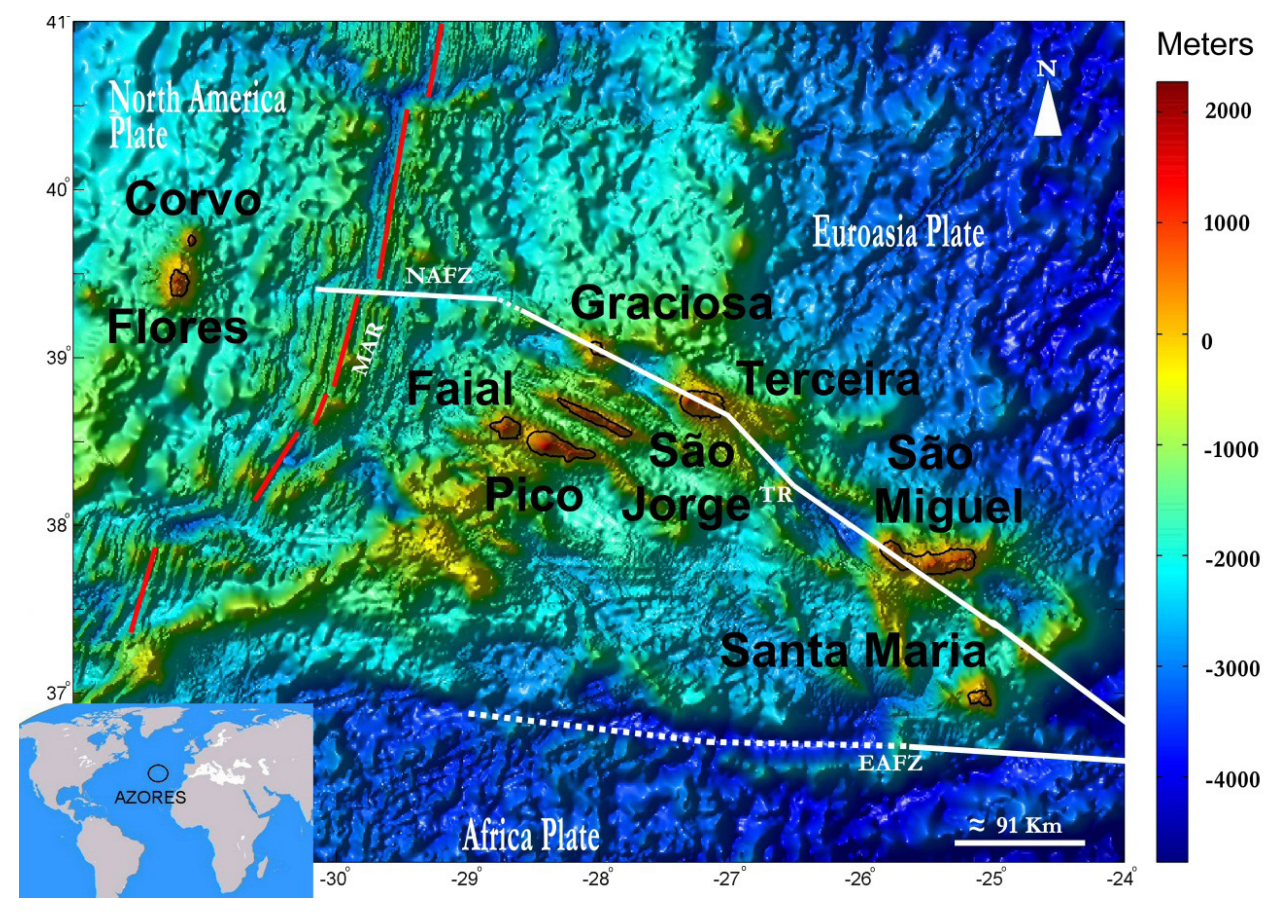

Figure 2. Location of the Azores Archipelago. Azores islands represent the emerged portion of Azores plateau, which is defined by the batimetric line of the 2000 meters. The Terceira Rift (TR), a structure that is part of the complex geodynamic setting, and is responsible for important seismovolcanic activity. MAR - Mid-Atlantic Ridge; NAFZ - North Azores Fracture Zone; EAFZ - East Azores Fracture Zone.

Figura 2. Localização do Arquipélago dos Açores. As ilhas representam a parte emersa da plataforma dos Açores que é definido pela linha batimétrica dos 2000m. O Rift da Terceira, estrutura que pertence ao referido complexo geodinâmico, é responsável pela importante actividade sismovulcânica. MAR - Crista Média Atlântica; NAFZ - Zona de Fractura Norte dos Açores; EAFZ - Zona de Fractura Este dos Açores.

Table 1. Geophysical characteristics of studied lakes (a - data from PRA; b - data from Morriseau, 1987; c - data from Gonçalves, et al., 2005; M and P in WGS 84; n/a - no data available).

Tabela 1. Características físicas dos lagos estudados (a-dados do PRA; $b$-dados de Morriseau, 1987; $C$-dados de Gonçalves et al., 2005; M e P no WGS 84; nla-sem dados).

\begin{tabular}{|c|c|c|c|c|c|c|c|c|c|c|}
\hline \multirow{2}{*}{ Lake } & \multicolumn{2}{|c|}{ Location } & \multirow{2}{*}{$\begin{array}{l}\text { Altitude } \\
\text { (m) }\end{array}$} & \multirow{2}{*}{$\begin{array}{l}\text { Area } \\
\left(\mathrm{km}^{2}\right)\end{array}$} & \multirow{2}{*}{$\begin{array}{l}\text { Lenght } \\
\text { (m) }\end{array}$} & \multirow{2}{*}{$\begin{array}{l}\text { Width } \\
\text { (m) }\end{array}$} & \multirow{2}{*}{$\begin{array}{l}\text { Depth } \\
\text { (m) }\end{array}$} & \multirow{2}{*}{$\begin{array}{l}\text { Volume } \\
\left(10^{3} \mathrm{~m}^{3}\right)\end{array}$} & \multirow{2}{*}{$\begin{array}{l}\text { Geological } \\
\text { classification }\end{array}$} & \multirow{2}{*}{$\begin{array}{c}\text { Water } \\
\text { quality (c) }\end{array}$} \\
\hline & M & $\mathbf{P}$ & & & & & & & & \\
\hline Negra & 652681 & 4367372 & 550 & 0.13 & 451 & 389 & 122 & 14822.2 & Maar (S.L) & $\mathrm{n} / \mathrm{a}$ \\
\hline Comprida & 652973 & 4367020 & 550 & 0.05 & 496 & 15 & 17 & ) & LL) & High \\
\hline Funda & 653325 & 4363026 & 355 & 0.35 & 873 & 635 & 33.5 & $\mathrm{n} / \mathrm{a}$ & Maar (S.L) & Bad \\
\hline Rasa & 652795 & 4363508 & 527 & 0.1 & 423 & 323 & 17 & 754 (a) & Cinder cone ${ }^{b}$ & High \\
\hline
\end{tabular}

\section{RESULTS}

Results of the field data (Table 2) show that the lake water was cold $\left(13-23.4^{\circ} \mathrm{C}\right)$ and thermally stratified during field work, except for Lake Comprida (May 2006). However, the profile did not reach the lake bottom. The Lake Negra thermocline occurs around $10 \mathrm{~m}$ to $30 \mathrm{~m}$ depth, which is deeper than at Funda, Comprida and Rasa Lakes (Fig. 3).

Despite the thermal stratification, the lake's water column was chemically close to homogeneous in all sampling profiles (Fig. 4). Lakes Negra and Comprida have the relatively highest concentration for all chemical elements, and the water samples taken from the other lakes are more diluted.

The ionic composition of the water samples induces relatively variable chemical facies. The smaller size lakes are $\mathrm{Na}-\mathrm{Cl}$ dominated, while the larger lakes become more Ca$\mathrm{HCO} 3$ dominated (Fig. 5).

The dissolved chemical elements in Negra and Funda Lakes show a relative distribution, which decreases in order for cations $\mathrm{Na}>\mathrm{Ca}>\mathrm{Mg}>\mathrm{K}$ and for anions $\mathrm{HCO}_{3}>\mathrm{Cl}>\mathrm{SO}_{4}$. However, the relative distribution of dissolved chemical 
Table 2. Major chemical elements compositions of Flores Lakes. All concentrations in ppm, depth in meters, Temperature (Temp.) in ${ }^{\circ} \mathrm{C}$ and electrical conductivity (Cond) in $\mu \mathrm{S} / \mathrm{cm}$.

Tabela 2. Resultado dos elementos maiores nos lagos estudados. As unidades dos elementos analisados estão em mg/L. A profundidade é medida em metros, a temperatura (Temp.) em ${ }^{\circ} \mathrm{C}$ e a Condutividade Eléctrica (Cond) em $\mu \mathrm{S} / \mathrm{cm}$. Elementos não determinados em branco.

\begin{tabular}{|c|c|c|c|c|c|c|c|c|c|c|c|c|c|c|c|c|c|c|c|}
\hline Lake & Date & Depth & $\mathrm{pH}$ & Temp & Cond & DO & freeCO $\mathrm{CO}_{2}$ & totalCO $\mathrm{CO}_{2}$ & $\mathrm{HCO}_{3}$ & Alk & $\mathrm{Cl}$ & $\mathrm{SO}_{4}$ & $\mathrm{Na}$ & $\mathbf{K}$ & $\mathbf{M g}$ & $\mathrm{Ca}$ & $\mathrm{SiO}_{2}$ & $\mathrm{Fe}$ & $\mathrm{NO}_{3}$ \\
\hline \multirow{13}{*}{ Negra } & May-06 & 0 & 7.54 & 14.8 & 143 & 9.4 & 1.8 & 37.0 & 48.8 & 40 & 16.1 & 3.8 & 14.1 & 1.6 & 4.8 & 7.2 & 12.1 & 0.12 & 3.6 \\
\hline & May-06 & 10 & 7.77 & 14.6 & 142 & 10.0 & 1.6 & 23.6 & 30.5 & 25 & 16.3 & 3.5 & 14.2 & 1.5 & 5.0 & 6.8 & 10.9 & 0.00 & 2.6 \\
\hline & May-06 & 20 & 8.20 & 14.2 & 142 & 9.6 & 3.0 & 38.2 & 48.8 & 40 & 16.3 & 3.6 & 14.1 & 1.5 & 4.7 & 7.0 & 11.4 & 0.00 & 1.4 \\
\hline & May-06 & 30 & 8.18 & 13.1 & 142 & 9.3 & 3.2 & 38.4 & 48.8 & 40 & 16.3 & 3.7 & 14.1 & 1.6 & 4.9 & 7.6 & 12.5 & 0.01 & 1.0 \\
\hline & May-06 & 40 & 7.84 & 13.0 & 141 & 8.2 & 2.6 & 37.8 & 48.8 & 40 & 16.1 & 3.7 & 14.2 & 1.6 & 5.2 & 7.8 & 12.5 & 0.01 & 1.5 \\
\hline & May-06 & 50 & 7.78 & 13.1 & 142 & 8.1 & 3.6 & 38.8 & 48.8 & 40 & 16.7 & 3.6 & 14.2 & 1.7 & 4.9 & 6.8 & 13.3 & 0.12 & 9.1 \\
\hline & May-06 & 60 & 8.21 & 13.1 & 141 & 8.3 & 2.8 & 40.2 & 51.9 & 43 & 16.4 & 3.8 & 14.1 & 1.6 & 4.9 & 6.8 & 13.6 & 0.06 & 0.7 \\
\hline & May-06 & 70 & 8.21 & 13.1 & 141 & 8.3 & 2.4 & 37.6 & 48.8 & 40 & 16.5 & 3.7 & 14.0 & 1.7 & 4.7 & 7.5 & 12.8 & 0.07 & 0.7 \\
\hline & May-06 & 80 & 8.08 & 13.5 & 140 & 8.2 & 2.8 & 38.9 & 50.0 & 41 & 16.5 & 3.6 & 14.2 & 1.6 & 4.7 & 7.4 & 13.2 & 0.07 & 1.8 \\
\hline & May-06 & 90 & 7.87 & 13.1 & 141 & 8.3 & 2.5 & 40.3 & 52.5 & 43 & 16.5 & 3.9 & 14.1 & 1.6 & 4.7 & 6.8 & 13.4 & 0.04 & 1.9 \\
\hline & May-06 & 100 & 8.09 & 13.1 & 141 & 8.2 & 3.3 & 41.1 & 52.5 & 43 & 16.2 & 3.7 & 14.1 & 1.6 & 5.0 & 6.9 & 13.0 & 0.01 & \\
\hline & May-06 & 110 & 8.22 & 13.1 & 141 & 8.3 & 2.6 & 37.8 & 48.8 & 40 & 16.6 & 3.8 & 14.3 & 1.6 & 4.7 & 7.2 & 13.0 & 0.04 & 5.2 \\
\hline & May-06 & 115 & 8.44 & 13.3 & 141 & 8.3 & 2.2 & 39.2 & 51.2 & 42 & 16.4 & 3.9 & 14.2 & 1.6 & 5.0 & 7.1 & 13.1 & 0.00 & 2.2 \\
\hline \multirow{15}{*}{ Comprida } & Jul-05 & 0 & 7.56 & 19.9 & 77 & & 0.6 & 11.2 & 14.6 & 12 & 14.0 & 2.7 & 10.8 & 1.1 & 1.9 & 4.4 & 3.4 & 0.08 & \\
\hline & Jul-05 & 3 & 7.40 & 19.0 & 76 & & 0.8 & 10.5 & 13.4 & 11 & 13.6 & 2.6 & 10.3 & 0.9 & 1.8 & 3.7 & 3.9 & 0.07 & \\
\hline & Jul-05 & 6 & 7.30 & 16.8 & 78 & & 1.3 & 11.0 & 13.4 & 11 & & & 10.9 & 1.1 & 2.0 & 3.6 & 4.4 & 0.06 & \\
\hline & Jul-05 & 9 & 7.18 & 16.2 & 79 & & 2.1 & 10.9 & 12.2 & 10 & & & 12.1 & 1.1 & 2.0 & 4.1 & 5.0 & 0.05 & \\
\hline & Jul-05 & 12 & 7.05 & 15.8 & 80 & & 2.2 & 11.9 & 13.4 & 11 & 14.5 & 2.8 & 15.7 & 1.4 & 2.5 & 5.3 & 5.6 & 0.05 & \\
\hline & Jul-05 & 15 & 6.95 & 15.7 & 81 & & 2.8 & 13.4 & 14.6 & 12 & 14.4 & 2.7 & 12.4 & 1.2 & 2.2 & 3.8 & 5.7 & 0.06 & \\
\hline & Jul-05 & 17 & 6.84 & 15.7 & 81 & & 2.6 & 13.2 & 14.6 & 12 & 14.5 & 2.7 & 9.8 & 1.0 & 2.3 & 1.8 & 6.1 & 0.07 & \\
\hline & May-06 & 0 & 7.71 & $14 . \overline{6}$ & $\overline{92}$ & 8.5 & $2 . \overline{6}$ & $14 . \overline{0}$ & 15.9 & 13 & $16 . \overline{1}$ & 3.1 & $\overline{10.5}$ & 1.0 & $2 . \overline{7}$ & 2.4 & $\overline{3.8}$ & 0.08 & \\
\hline & May-06 & 3 & 7.42 & 14.8 & 92 & 8.8 & 2.4 & 15.6 & 18.3 & 15 & 15.9 & 3.0 & 10.4 & 1.0 & 2.6 & 2.3 & 3.3 & 0.05 & \\
\hline & May-06 & 6 & 7.39 & 14.7 & 91 & 8.7 & 2.0 & 14.3 & 17.1 & 14 & 16.2 & 3.0 & 10.6 & 1.0 & 2.6 & 2.3 & 3.4 & 0.05 & 0.5 \\
\hline & May-06 & 9 & 7.22 & 14.6 & 92 & 8.6 & 2.2 & 15.4 & 18.3 & 15 & 16.1 & 2.9 & 10.5 & 1.0 & 2.7 & 2.4 & 3.0 & 0.09 & 0.8 \\
\hline & May-06 & 10 & 7.32 & 14.7 & 91 & 9.2 & 1.7 & 14.9 & 18.3 & 15 & 16.0 & 3.0 & 10.4 & 1.0 & 3.1 & 2.3 & 3.1 & 0.04 & \\
\hline & Jul-07 & 0 & & & & $10 \overline{6}$ & 3.2 & $\overline{14.6}$ & $15 . \overline{9}$ & $\overline{13}$ & $\overline{15.6}$ & 3.0 & $9 . \overline{8}$ & $\overline{1.3}$ & $\overline{2.4}$ & 1.9 & $5 . \overline{0}$ & $0 . \overline{12}$ & \\
\hline & Jul-07 & 8 & & & & 9.9 & 2.8 & 14.2 & 15.9 & 13 & 15.7 & 2.9 & 9.8 & 1.2 & 2.4 & 1.9 & 5.6 & 0.10 & \\
\hline & Jul-07 & 15 & & & & 9.9 & 3.3 & 14.3 & 15.3 & 13 & 15.5 & 3.0 & 9.8 & 1.3 & 2.4 & 1.9 & 5.3 & 0.15 & \\
\hline \multirow{23}{*}{ Funda } & Jul-05 & 0 & 9.94 & 23.4 & 148 & & 1.0 & 24.8 & 32.9 & 27 & 17.7 & 3.0 & 12.5 & 1.5 & 3.5 & 4.4 & 7.4 & 0.02 & \\
\hline & Jul-05 & 5 & 8.30 & 17.9 & 124 & & 1.4 & 27.8 & 36.6 & 30 & 18.6 & 3.2 & 14.3 & 1.7 & 3.6 & 8.0 & 7.5 & 0.03 & \\
\hline & Jul-05 & 10 & 7.85 & 16.9 & 125 & & 2.8 & 26.6 & 32.9 & 27 & 17.7 & 3.2 & 13.1 & 1.6 & 3.4 & 7.4 & 8.0 & 0.02 & \\
\hline & Jul-05 & 15 & 7.51 & 15.1 & 130 & & 3.0 & 27.6 & 34.2 & 28 & 18.4 & 3.3 & 13.3 & 1.7 & 3.5 & 7.8 & 7.2 & 0.01 & \\
\hline & Jul-05 & 20 & 7.85 & 14.9 & 128 & & 4.2 & 29.3 & 34.8 & 29 & 18.7 & 3.3 & 13.2 & 1.7 & 3.4 & 7.4 & 6.5 & 0.03 & \\
\hline & Jul-05 & 25 & 7.56 & 14.4 & 131 & & 6.6 & 33.0 & 36.6 & 30 & 18.8 & 3.2 & 13.2 & 1.7 & 3.6 & 7.6 & 7.1 & 1.23 & \\
\hline & Jul-05 & 30 & 7.10 & 14.0 & 135 & & 8.4 & 38.3 & 41.5 & 34 & 18.8 & 3.1 & 12.9 & 1.7 & 3.6 & 7.7 & 7.0 & 0.04 & \\
\hline & Jul-05 & 33 & 6.71 & 13.8 & 123 & & 7.2 & 36.2 & _40.3 & 33 & 18.9 & 2.9 & 13.4 & 1.9 & 3.7 & 4.0 & 7.2 & $0 . \underline{48}$ & \\
\hline & May-06 & 0 & $9 . \overline{26}$ & $\overline{16.0}$ & 137 & $9 \overline{6}$ & & & $45 . \overline{1}$ & $\overline{37}$ & $\overline{18.0}$ & 3.2 & $13 . \overline{9}$ & $\overline{1.7}$ & $\overline{4.0}$ & 6.0 & $5 . \overline{2}$ & $0 . \overline{05}$ & \\
\hline & May-06 & 3 & 9.35 & 16.0 & 137 & 9.3 & & & 40.3 & 33 & 18.2 & 3.4 & 13.9 & 1.7 & 4.6 & 6.4 & 5.4 & 0.08 & 4.9 \\
\hline & May-06 & 6 & 9.46 & 16.0 & 137 & 9.3 & & & & & 17.7 & 3.2 & 13.8 & 1.7 & 4.4 & 5.8 & 5.9 & 0.04 & 2.3 \\
\hline & May-06 & 9 & 9.53 & 16.0 & 137 & 9.3 & & & 43.9 & 36 & 17.7 & 3.5 & 14.0 & 1.7 & 4.6 & 7.6 & 6.0 & 0.06 & 1.2 \\
\hline & May-06 & 12 & 9.42 & 14.4 & 134 & 7.0 & & & 42.7 & 35 & 17.7 & 3.4 & 13.8 & 1.7 & 4.4 & 6.6 & 6.9 & 0.09 & 1.5 \\
\hline & May-06 & 15 & 9.02 & 13.6 & 132 & 7.1 & & & 40.9 & 34 & 18.1 & 3.3 & 13.7 & 1.7 & 4.5 & 5.9 & 6.6 & 0.03 & 3.1 \\
\hline & May-06 & 18 & 8.45 & 13.5 & 131 & 7.1 & & & 40.6 & 33 & 17.4 & 3.3 & 13.6 & 1.7 & 4.4 & 5.6 & 6.4 & 0.03 & 1.0 \\
\hline & May-06 & 21 & 8.19 & 13.5 & 132 & 7.1 & & & 41.5 & 34 & 17.7 & 3.1 & 13.7 & 1.7 & 4.1 & 5.6 & 6.3 & 0.03 & 2.4 \\
\hline & May-06 & 24 & 7.93 & 13.4 & 131 & 4.5 & 5.0 & 34.0 & 40.3 & 33 & 11.4 & 2.3 & 13.6 & 1.7 & 4.5 & 5.8 & 6.9 & 0.11 & 1.8 \\
\hline & May-06 & 27 & 7.76 & 13.3 & 133 & 3.3 & 6.8 & 36.3 & 40.9 & 34 & 17.3 & 3.2 & 13.5 & 1.7 & -4.3 & 5.9 & 7.3 & 0.09 & 2.3 \\
\hline & $\overline{\text { Jul-07}}$ & $\overline{0}$ & & & & & & & $\overline{40.3}$ & 30 & $19 . \overline{2}$ & $\overline{3.4}$ & $\overline{13.8}$ & 1.5 & $4 . \overline{4}$ & 6.3 & $\overline{5.7}$ & 0.01 & \\
\hline & Jul-07 & 6 & & & & & & & 39.7 & 33 & 18.9 & 3.5 & 13.5 & 1.5 & 4.2 & 6.2 & 4.8 & 0.03 & \\
\hline & Jul-07 & 12 & & & & & 1.5 & 31.4 & 41.5 & 34 & 18.9 & 3.8 & 14.0 & 1.7 & 4.2 & 6.4 & 6.6 & 0.14 & 1.0 \\
\hline & Jul-07 & 16 & & & & & 7.2 & 35.8 & 39.7 & 33 & 19.1 & 3.7 & 13.8 & 1.6 & 4.5 & 5.9 & 5.6 & 0.02 & 0.6 \\
\hline & Jul-07 & 23 & & & & & 8.0 & 34.0 & 39.0 & 32 & 19.1 & 3.7 & 13.8 & 1.7 & 4.2 & 5.7 & 5.8 & 0.25 & \\
\hline \multirow{7}{*}{ Rasa } & Jul-05 & 0 & 7.38 & 21.6 & 66 & & 1.0 & 2.3 & 1.8 & 2 & 15.6 & 2.8 & 9.2 & 0.6 & 0.7 & 1.4 & 1.5 & 0.09 & \\
\hline & Jul-05 & 5 & 7.10 & 19.8 & 66 & & 1.0 & 2.3 & 1.8 & 2 & 15.8 & 2.8 & 8.8 & 0.4 & 0.4 & 1.3 & 2.4 & 0.03 & \\
\hline & Jul-05 & 10 & 6.87 & 17.1 & 66 & & 1.2 & 2.1 & 1.2 & 2 & 16.1 & 2.9 & 8.9 & 0.4 & 0.4 & 1.3 & 2.3 & 0.12 & \\
\hline & Jul-05 & 17 & 6.22 & 16.7 & 67 & & 3.2 & $\underline{4.5}$ & 1.8 & $\underline{2}$ & $\underline{16.2}$ & 2.8 & 8.7 & 0.4 & 0.4 & 1.4 & 3.0 & 0.08 & \\
\hline & Jul-07 & 0 & $6 . \overline{26}$ & 19.6 & 68 & 7.0 & 2.6 & 6.1 & $4 . \overline{9}$ & 4 & $\overline{17.1}$ & 3.1 & $9 . \overline{2}$ & 0.4 & 0.4 & 1.3 & $1 . \overline{3}$ & $0 . \overline{08}$ & \\
\hline & Jul-07 & 7 & 6.27 & 18.7 & 68 & 6.6 & 2.3 & 4.1 & 2.4 & 2 & 17.2 & 3.1 & 9.2 & 0.4 & 0.4 & 1.3 & 1.1 & 0.04 & \\
\hline & Jul-07 & 14 & 5.43 & 15.1 & 71 & 3.5 & 2.6 & 7.0 & 6.1 & 5 & 17.6 & 3.1 & 9.5 & 0.5 & 0.4 & 1.4 & 1.5 & 0.11 & \\
\hline
\end{tabular}




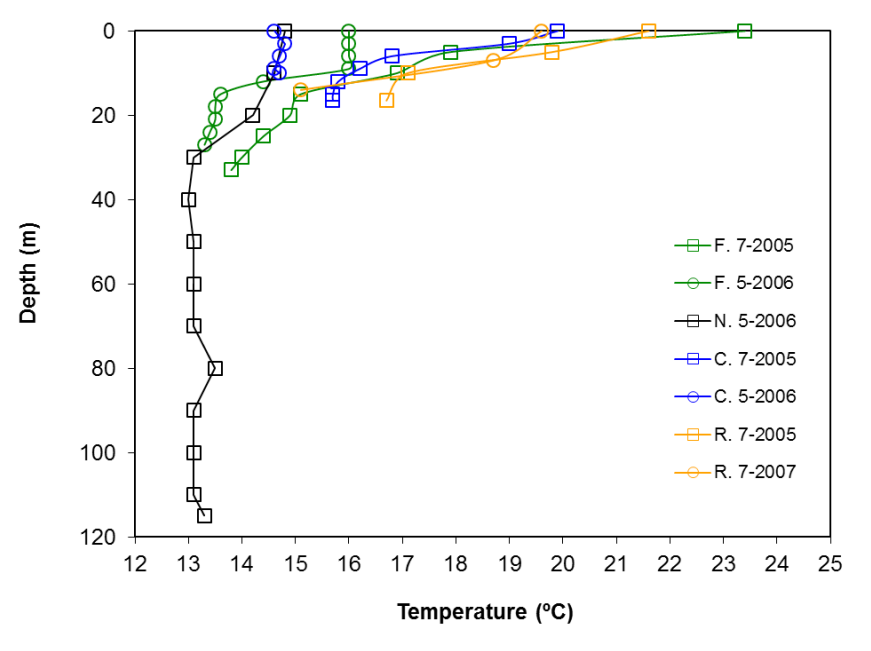

Figure 3. Temperature variation with depth. Vertical profile from Negra Lake show a depth thermocline compared with other lakes. F. - Funda Lake, N. - Negra Lake, C. - Comprida Lake, R. - Rasa Lake.

Figura 3. Variação da temperatura ao longo da coluna de água. $O$ perfil realizado na Lagoa Negra mostra a existência de uma termoclina mais profunda comparativamente com os restantes lagos. F. - Lagoa Funda, N. - Lagoa Negra, C. - Lagoa Comprida, R. - Lagoa Rasa.

elements in Lake Comprida ( $\left.\mathrm{Na}>\mathrm{Ca}-\mathrm{Mg}>\mathrm{K} ; \mathrm{HCO}_{3}-\mathrm{Cl}>\mathrm{SO}_{4}\right)$ is distinct from Lake Rasa $\left(\mathrm{Na}>\mathrm{Ca}>\mathrm{Mg}-\mathrm{K} ; \mathrm{Cl}>\mathrm{SO}_{4}>\mathrm{HCO}_{3}\right)$. Water samples from Lake Comprida, a smaller lake in area and volume, show a slightly more concentrated water composition and provide mixed facies with a $\mathrm{Ca}-\mathrm{Mg}-\mathrm{HCO} 3$ enrichment compared to Lake Rasa.

The $\mathrm{pH}$ values for all sampled lakes range between 5.43 and 9.94 and decrease with depth to slightly acidic values, except for Lake Negra waters which have alkaline values and the $\mathrm{pH}$ increases slightly with depth (Fig. 6). The total $\mathrm{CO}_{2}$ concentrations show a pattern to increase in the hipolimnion (Fig. 7)

The DO vertical profiles show well oxygenated waters for Lake Negra and Comprida (Fig. 8). Lake Funda and Rasa have an oxygen-rich epilimnion above the thermocline and an anoxic hipolimnion.

\section{DISCUSSION}

Temperature affects the chemical equilibrium of aquatic systems (Wetzel, 1993; Lampert et al., 2007). Thermal stratification is common in Azorean lakes in the summer with depths greater than $12 \mathrm{~m}$ and thermoclines between 3 and 20m (Antunes, 2009). Lake Negra is the deepest lake in the Azores and shows a thermocline larger than the other lakes. Lake water stratification prevents water from circulating between the epilimnion and the hypolimnion. However, lakes sampled in Flores do not show strong compositional stratification. More campaigns are needed to determine the thermal water gradient over the course of the year at the study lakes. Lake waters show low levels of mineralization, with low electrical conductivity values $(<148 \mu \mathrm{S} / \mathrm{cm}$; Table 2$)$. The marine contribution, due to sea salt input by atmospheric deposition, partially controls the hydrogeochemical evolution of the lakes where water samples are near the line that characterizes the sea water line (Fig. 9).

Marine contribution is the main mechanism that controls the water chemistry of Lake Rasa, which has the most dilute water of the sampled lakes with $\mathrm{Na}-\mathrm{Cl}$ facies (Fig. 5) that are located close the sea water line. Lake Comprida water samples are disperse on the plot, which results from the mixed mineral water springs that drain into the lake and contribute to slightly more concentrated water than Lake Rasa (Table 3 and Figure 9).

Despite the marine contribution, the effect of water-rock interaction processes contributes to water composition in the large mass lakes with the large concentration of alkali metal (Fig. 10). The slightly $\mathrm{CO}_{2}$ production by organic matter contributes to the acidity of the hipolimnion and is responsible for the $\mathrm{pH}$ decrease (Fig. 6, 7 and 11).

Figure 11 compares the studied Flores lakes with the Congro and Furnas Lake at São Miguel Island and with Furna do Enxofre Lake (F. Enxofre) at Graciosa Island. F. Enxofre is a small lake inside a basaltic lava cave located at the Caldera of Graciosa volcano (Fig. 12).

There is a fumarole field inside the cave and it is possible to see vapour at 1 meter depth along the lake margin. In the summer, $\mathrm{CO}_{2}$ concentrations above the surface water reaches $17 \%$ and it is the Azorean lake with the highest $\mathrm{CO}_{2}$ concentration. Furnas Lake water contamination has a contribution from a hydrothermal surface manifestation, with fumarole discharge located on the northern margin of the lake. Congro Lake water contamination by volcanic fluids does not have a clear pattern, but magmatic contribution cannot be excluded (Antunes 2009). The free $\mathrm{CO}_{2}$ concentration in Flores water lakes are lower than lakes with clear signatures of volcanic fluids contamination and show a different trend. Lake Rasa has the lowest $\mathrm{pH}$ values resulting from the process that controls the water chemistry, suggesting a low water residence time. Lake Funda shows the highest values of $\mathrm{pH}$ at the water surface due to the intense biological activity that occurs in this system. Indeed, the phytoplankton enriched epilimnion, shown by the chlorophyll $a$ and phaeopigments, exceeds the concentration present at other lakes (Table 4).

Lake water eutrophication is the main source of aquatic system degradation. The lakes have been subject to unprecedented level of anthropogenic disturbance and eutrophication, which makes Azorean lakes highly productive systems (INOVA, 1999; Gonçalves, 1997; Gonçalves et al., 2005, Aguiar et al., 2008; Gonçalves, 2008). Biological production by photosynthesis, leads to high $\mathrm{pH}$ values on lake epilimnions and the increase of water opacity contributes to increased heat retention. Highly productive aquatic systems represent a potential hazard as the cyanobacteria produce hepatic toxins and neurotoxins, which are responsible for acute lethal, acute, chronic and sub-chronic poisonings of animals and humans (Carmichael, 2001; Ellwood et al., 2005). 

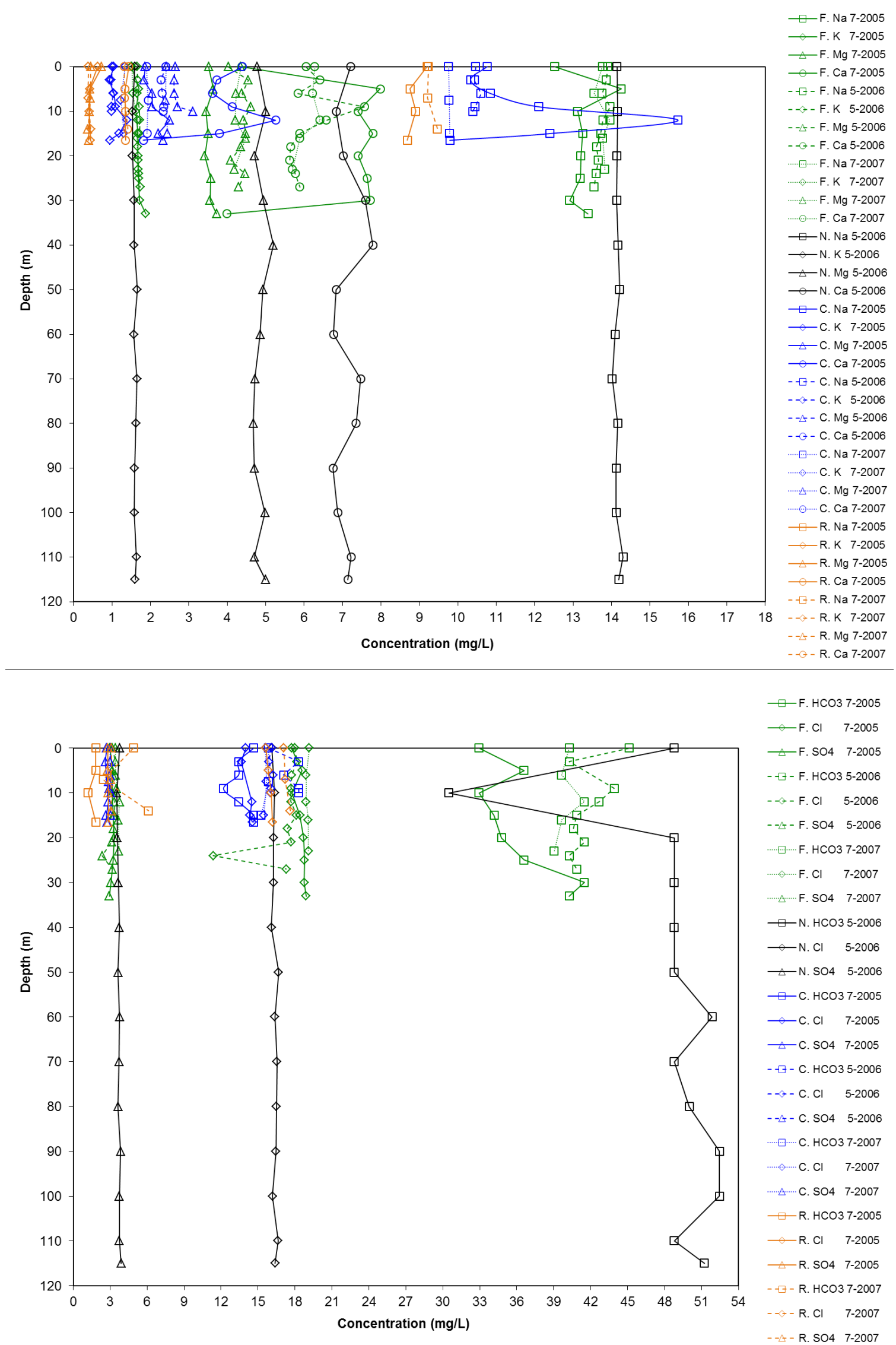

Figure 4. Vertical profiles showing the major chemical elements in the studied aquatic systems. F. - Lagoa Funda, N. - Lagoa Negra, C. - Lagoa Comprida, R. - Lagoa Rasa.

Figura 4. Resultado dos elementos maiores ao longo da coluna de água nos lagos estudados. F. - Funda Lake, N. Negra Lake, C. - Comprida Lake, R. - Rasa Lake. 


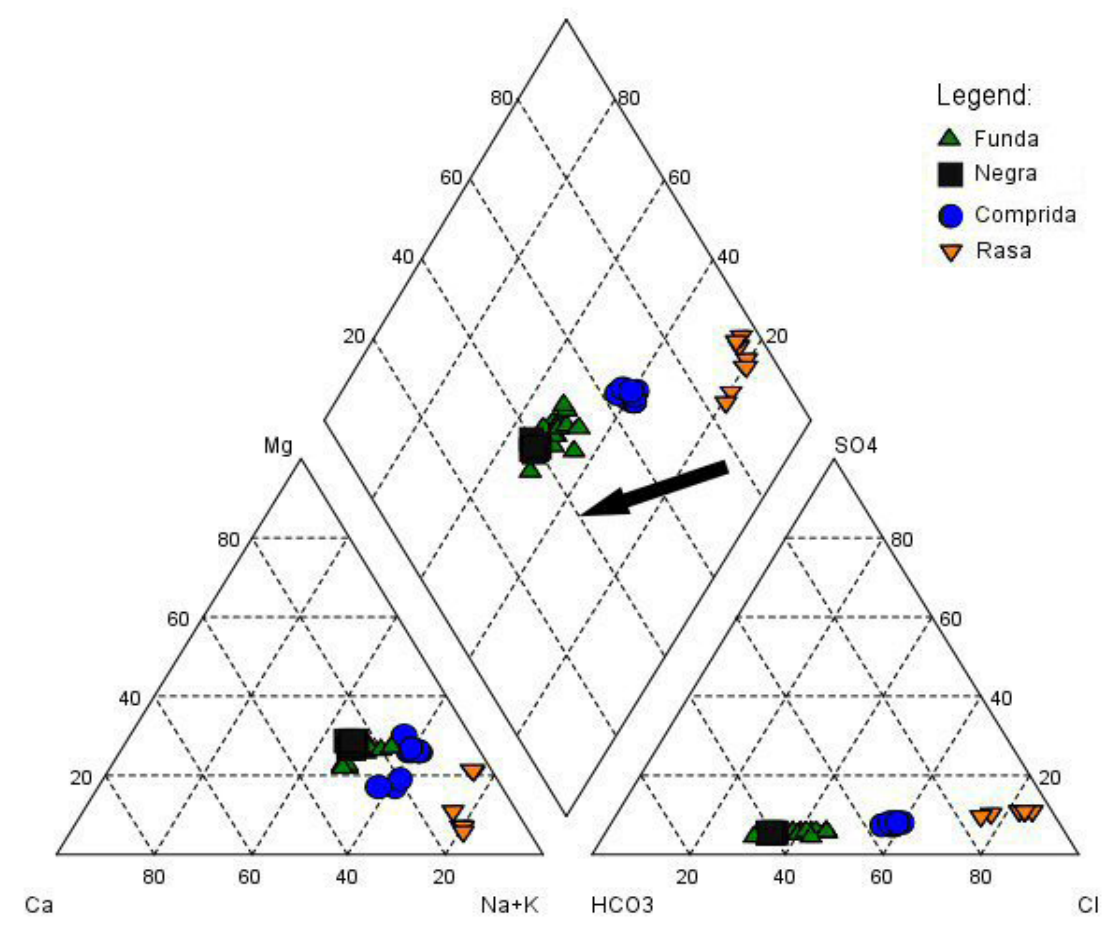

Figure 5. Piper diagram applied to a representative set of samples (data from Table 2). Figura 5. Diagrama de Piper representado por um conjunto significativo de amostras de água dos lagos amostrados e que constam na Tabela 2.

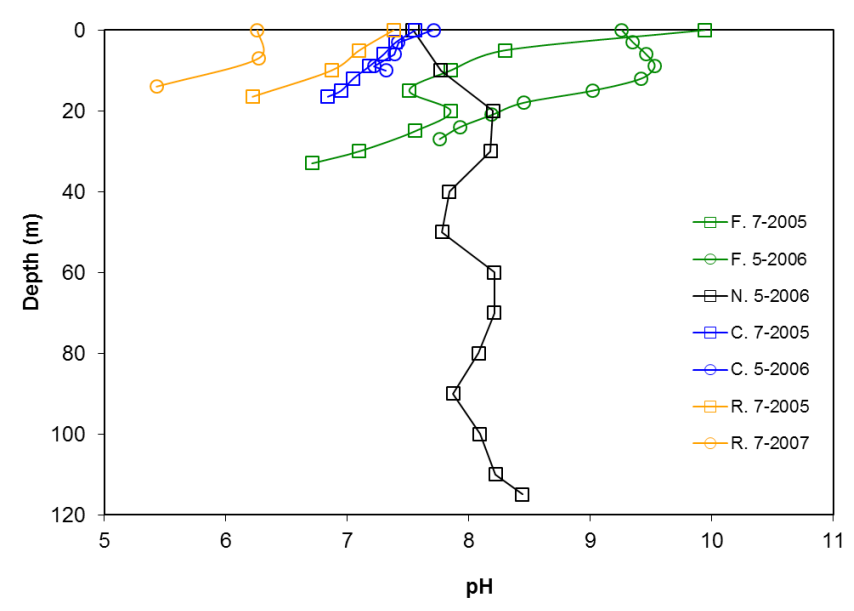

Figure 6. Variation of $\mathrm{pH}$ with depth in the sampled lakes. Lake Negra is the only lake $\mathrm{pH}$ increased in depth. F. - Funda Lake, N. - Negra Lake, C. - Comprida Lake, R. - Rasa Lake.

Figura 6. Variação do $p H$ em profundidade nos lagos estudados. A Lagoa Negra é o único lago que mostra um aumento do valor de $\mathrm{pH}$ em profundidade. F. - Lagoa Funda, N. - Lagoa Negra, C. - Lagoa Comprida, R. - Lagoa Rasa.

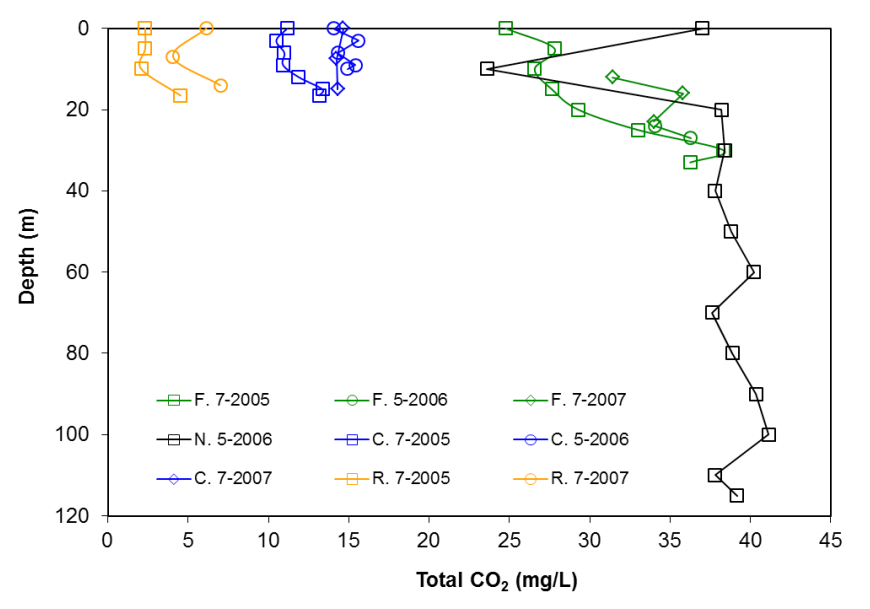

Figure 7. TotalCO2 concentration variation with depth for the sampled lakes. F. - Funda Lake, N. - Negra Lake, C. - Comprida Lake, R. - Rasa Lake.

Figura 7. Resultado do dióxido de carbono total em profundidade nos lagos estudados. F. - Lagoa Funda, N. - Lagoa Negra, C. - Lagoa Comprida, R. - Lagoa Rasa. 


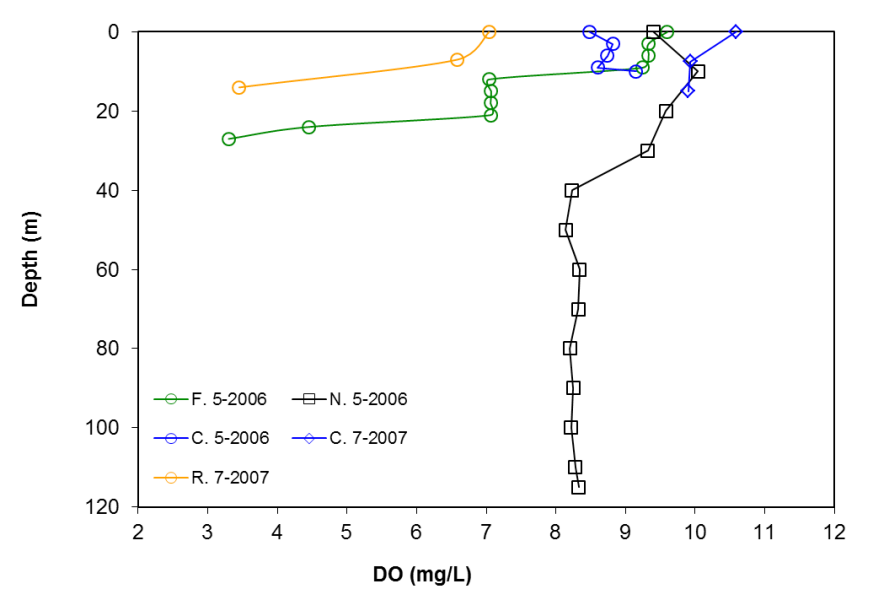

Figure 8. DO variation with depth for the sampled lakes. F. Funda Lake, N. - Negra Lake, C. - Comprida Lake, R. - Rasa Lake.

Figura 8. Variação do oxigénio dissolvido em profundidade nos lagos estudados. F. - Lagoa Funda, N. - Lagoa Negra, C. - Lagoa Comprida, R. - Lagoa Rasa.

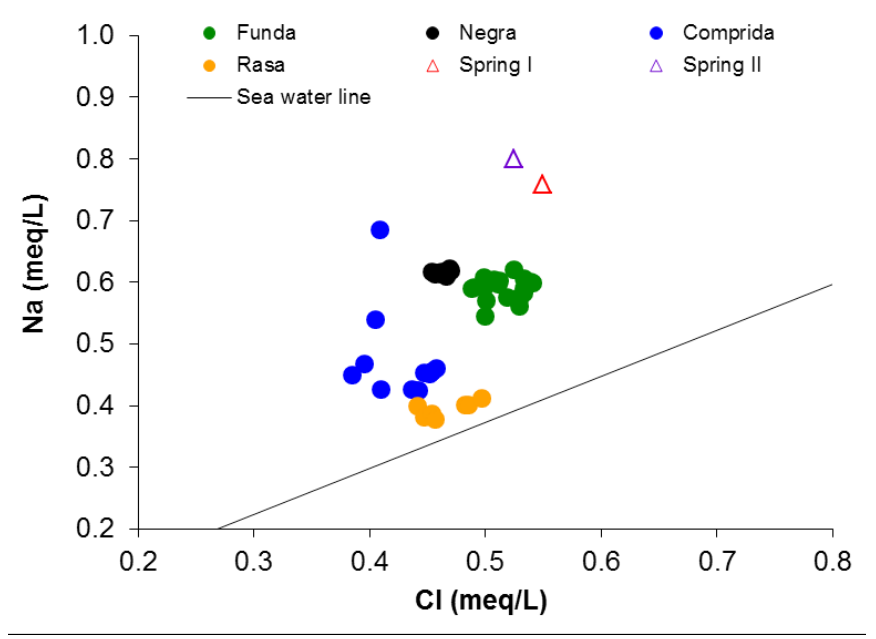

Figure 9. Compositional distribution of water samples related with the seawater line.

Figure 9. Distribuição da amostras de água em relação à recta que caracteriza a água do mar.

Table 3. Major chemical elements composition of springs located at the SE rim of Lake Comprida. All concentrations in ppm, temperature (Temp) in ${ }^{\circ} \mathrm{C}$ and electrical conductivity (Cond) in $\mu \mathrm{S} / \mathrm{cm}$.

Tabela 3. Resultado dos elementos maiores das nascentes localizadas no flanco SE da Lagoa Comprida. As unidades dos elementos analisados estão em $\mathrm{mg} / \mathrm{L}$, excepto para o $\mathrm{pH}$. A temperatura $(T) \mathrm{em}{ }^{\circ} \mathrm{C}$ e a Condutividade Eléctrica (Cond) em $\mu \mathrm{S} / \mathrm{cm}$.

\begin{tabular}{ccccccccccccccccc}
\hline Springs & $\mathbf{p H}$ & $\mathrm{Temp}$ & Cond & $\mathbf{D O}$ & freeCO$_{2}$ & totalCO$_{2}$ & $\mathbf{H C O}_{3}$ & $\mathbf{A l k}$ & $\mathbf{C l}$ & $\mathbf{S O}_{4}$ & $\mathbf{N a}$ & $\mathbf{K}$ & $\mathbf{M g}$ & $\mathbf{C a}$ & $\mathbf{S i O}_{2}$ & $\mathbf{F e}$ \\
\hline I & 6.68 & 12.6 & 365 & 0.3 & 21 & 159 & 192 & 157.5 & 19.5 & 1.9 & 17.5 & 6.6 & 21.6 & 69.9 & 43.7 & 0.05 \\
II & 7.08 & 14.5 & 367 & 0.3 & 24 & 181 & 218 & 178.5 & 18.6 & 1.5 & 18.4 & 6.6 & 24.3 & 98.7 & 43.7 & 3.08 \\
\hline
\end{tabular}
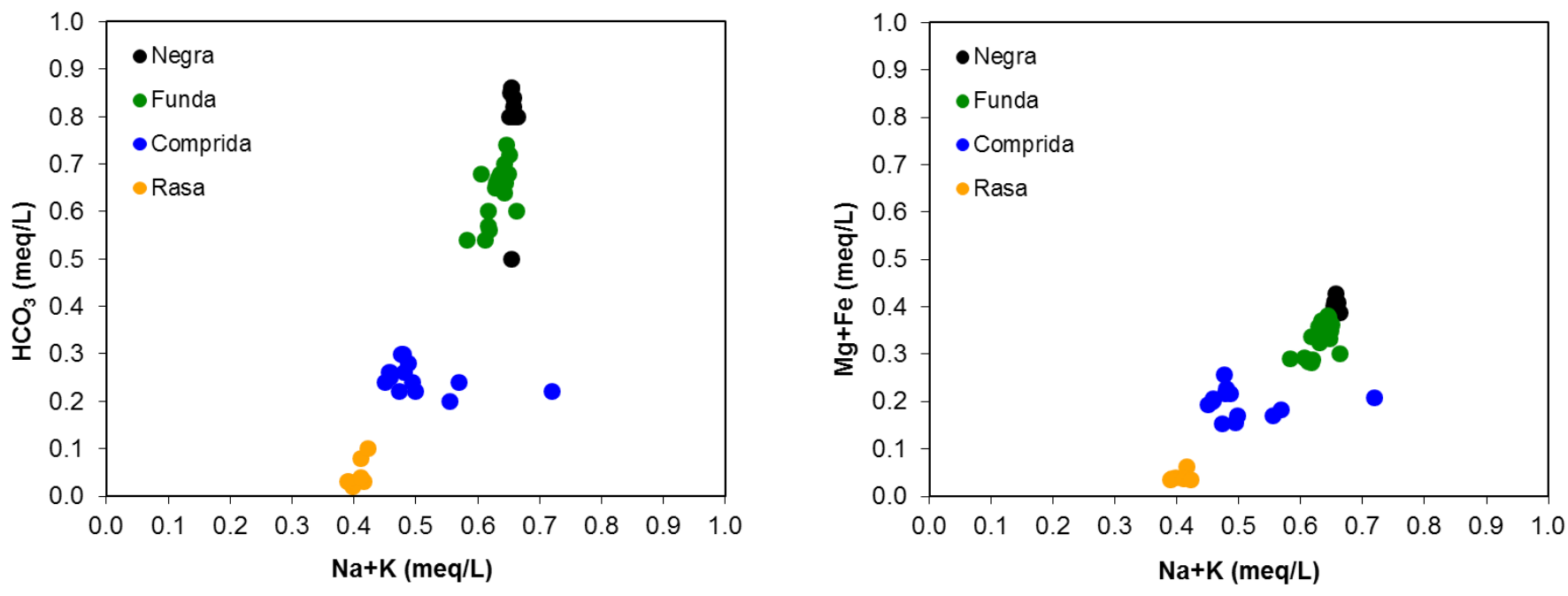

Figure 10. Compositional trend show an increase concentration for the large lakes.

Figura 10. A distribuição da amostras de água demostra a entrada dos elementos químicos nos lagos de maiores dimensóes. 


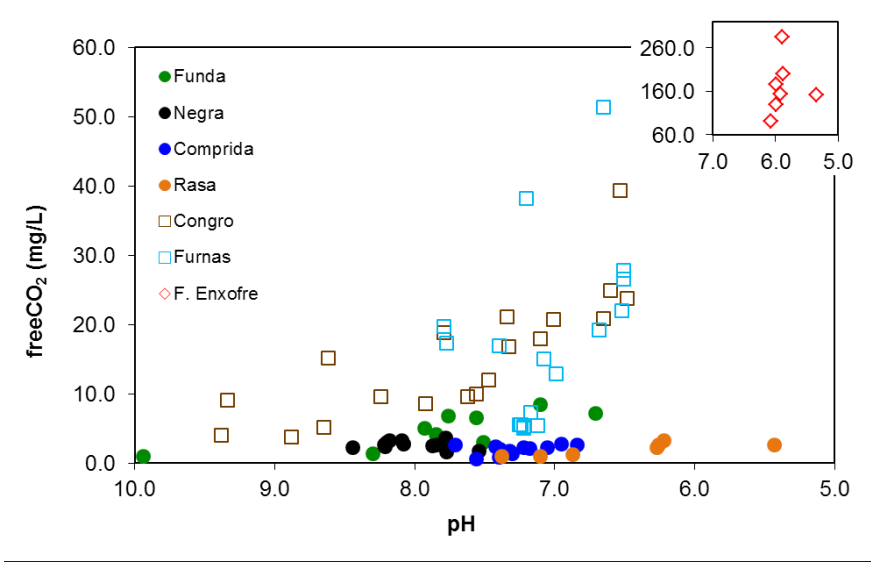

Figure 11. Variation of free $\mathrm{CO}_{2}$ vs $\mathrm{pH}$ in the studied lakes compared with Congro, Furnas and F. Enxofre Lakes.

Figura 11. Relaçáo entre o dióxido de carbono dissolvido e o pH nos lagos estudados, na Lagoa do Congro, das Furnas e da Furna do Enxofre.
Table 4. chlorophyll $\boldsymbol{a}$ and phaeopigments values sampled in Lakes Funda Comprida and Rasa during the samples campaign of 2007 (in Aguiar et al., 2008).

Tabela 4. Valores da clorofila a e de feopigmentos das amostras de água analisada nas Lagoas Funda, Comprida e Rasa durante a campanha de amostragem de 2007 (in Aguiar et al., 2008).

\begin{tabular}{|c|c|c|c|}
\hline & $\begin{array}{l}\text { Depth } \\
\text { (m) }\end{array}$ & $\begin{array}{c}\text { Chlorophyll a } \\
\text { (ug/L) }\end{array}$ & $\begin{array}{c}\text { Phaeopigments } \\
\text { (ug/L) }\end{array}$ \\
\hline \multirow{3}{*}{$\begin{array}{l}\text { Lake } \\
\text { Funda }\end{array}$} & 6 & 29.24 & 7.23 \\
\hline & 11 & 6.8 & 2.72 \\
\hline & 23 & 2.27 & 0.62 \\
\hline \multirow{3}{*}{$\begin{array}{l}\text { Lake } \\
\text { Comprida }\end{array}$} & 0 & 2.68 & 0.64 \\
\hline & 7.5 & 3.09 & 1.09 \\
\hline & 10 & 2.88 & 1.3 \\
\hline \multirow{3}{*}{$\begin{array}{l}\text { Lake } \\
\text { Rasa }\end{array}$} & 0 & 0.82 & 0.04 \\
\hline & 7 & 1.03 & 0.41 \\
\hline & 14 & 1.85 & 1.17 \\
\hline
\end{tabular}

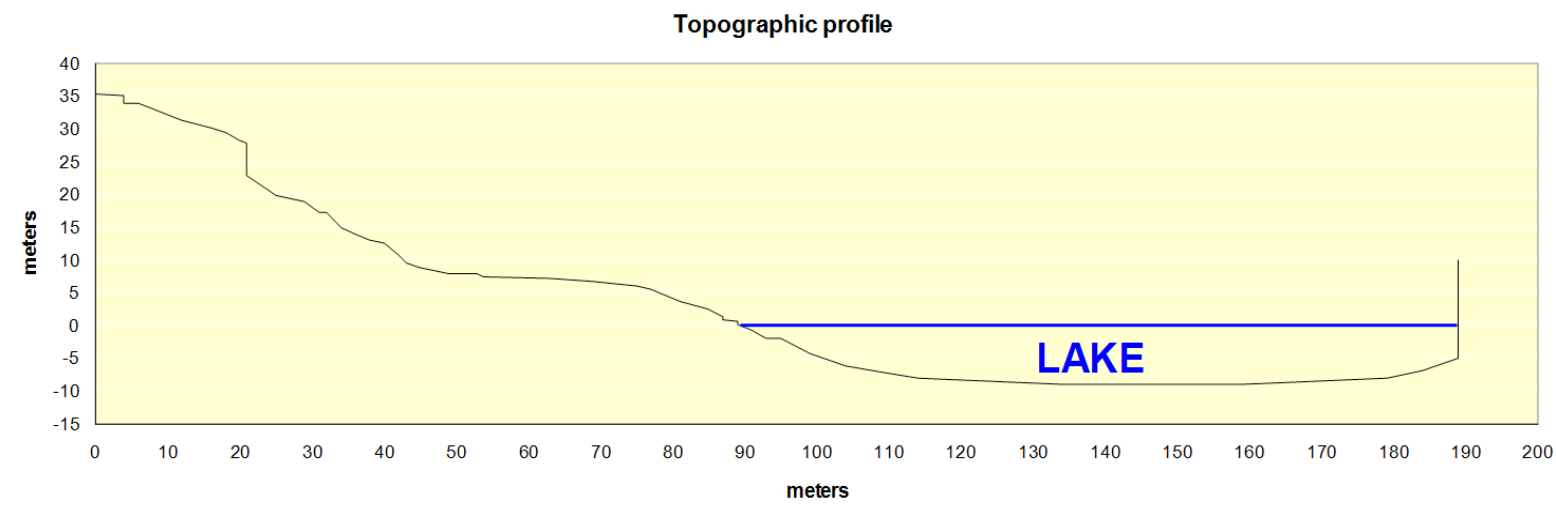

Figure 12. Topographic profile made along the interior of Furna do Enxofre cave. The lake occupied the lower and final part of the cave. The interior ceiling has a vault shape.

Figura 12. Perfil topográfico realizado no interior da Furna do Enxofre. O lago ocupa a zona mais deprimida da gruta localizada na parte oposta à sua entrada. O tecto da gruta tem forma de abóboda.

The $\mathrm{CO}_{2}$ concentration is dominant in the large mass of the lakes and Lake Funda shows a slight increase in $\mathrm{CO}_{2}$ with depth that might be explained by the decay of organic matter (Fig. 7). Funda lakes are anoxic during the sampling campaigns and the production of organic $\mathrm{CO}_{2}$ by anaerobiosis is inefficient compared with the aerobiosis process. The larger $\mathrm{CO}_{2}$ prodution in Funda lake can be explain by the large biological production as the phytoplankton enriched epilimnion shows.

The alkalinity acts as a buffer and neutralizes the acidic solutions that enter the aquatic systems. This buffer system protects aquatic organisms against changes in $\mathrm{pH}$, which converts the acid carbon into carbonate or bicarbonate (Wetzel, 1993; Wilson, 1995; Deutsch, 1997). Funda and Negra Lakes have the largest alkalinity values resulting from the neutralization of acid solution from the slightly free $\mathrm{CO}_{2}$ input by the chemical weathering of the volcanic rocks. This geochemical process contributes to the hydrogeochemical evolution of the larger mass lakes. Figure 10 shows the slight enrichment of alkali metals in Negra and Funda Lakes. Adding the Congro, Furnas and F. Enxofre results to the same plots, it is possible to identify two trends: one for São Miguel Lakes and another for Flores Lakes (Fig. 13).

Negra and Funda Lakes show a small increase in alkali metals related to bicarbonate. However, São Miguel Lakes show a higher increased in alkali metals due to the volcanic contribution, mainly in Furnas Lake. Comprida Lake shows an alkali metal increase independent of the bicarbonate content related to the water drained by mineral springs, which has a higher concentration in sodium and potassium 


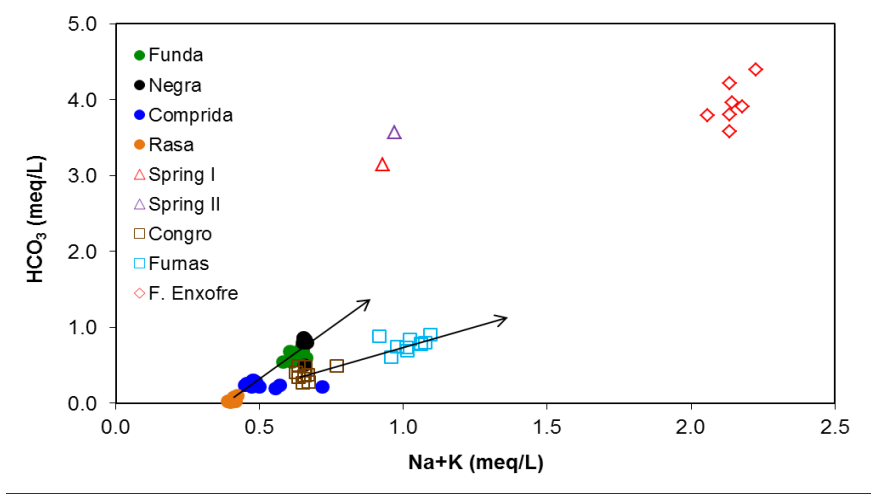

Figure 13. Compositional trend comparing the increase concentration for Flores, São Miguel and Graciosa Lakes. Congro e Furnas Lakes data correspond to the average of monthly sampling profiles and $\mathrm{F}$. Enxofre data correspond to July and November sampling profiles.

Figura 13. Comparação da distribuição dos metais alcalinos vs bicarbonato entre os lagos estudados e aos lagos localizados na ilha de São Miguel e Graciosa. Os dados referentes à Lagoa do Congro e Furnas dizem respeito às médias dos perfis efectuados mensalmente. Os resultados apresentados da Furna do Enxofre correspondem aos perfis efectuados em Julho e Novembro de 2006.

than Comprida Lake. Nevertheless, the higher content of alkali metals in F. Enxofre Lake is related to the weathering of silicate minerals due to hydrothermal water seepage (Fig. 13). Potassium is a conservative element present in minerals more resistant to hydrolysis, however this element is preferentially leached by high temperature fluids (Berner \& Berner, 1996; Albarède, 2003). São Miguel lakes, mainly Furnas Lake present a potassium increase consistent with the large mobilization of this element related to hydrothermal water seepage.

The compositional trend in large mass lakes at Flores Island shows quite clearly that bicarbonate increases independently from potassium.

Rock hydrolysis explains the slightly concentrated water in Funda and Negra Lakes compare to Comprida and Rasa Lakes. Although, the carbon dioxide, major ions and silica fluxes are very modest in the studied aquatic systems, which suggest no interaction with volcanic fluids. A contribution of $\mathrm{CO}$ from dominant volatile sources in Azorean lakes located at the summit of active craters is common and present an increase of bicarbonate and electrical conductivity at the hipolimnion (Antunes, 2009).

The profile variation of $\mathrm{Ca}, \mathrm{HCO}_{3}$ and $\mathrm{SiO}_{2}$ at Lake Funda could be explained by the phytoplankton metabolism (Wetzel, 1993).

The lake water quality degradation is related to anthropogenic influences. The input of artificial nutrients is the major cause of water quality degradation, inducing for example the extinction of small lakes such as Lagoa do Ginjal on Terceira and Lagoa dos Nenúfares on São Miguel due to eutrophication (Antunes \& Rodrigues, 2011). In general, the most eutrophic aquatic systems in the Azores occur in basins where the surrounding land is exploited by the livestock industry. In the Regional Water Plan for the Azores, fertilizer application rates for the agricultural area (UAA) were 352 and $707 \mathrm{~kg}$ ha- 1 for PK and NPK, respectively (DROTRH-INAG, 2001), and excessive use of these compounds may lead to greater mobility of nutrients into lakes. Nitrate $\left(\mathrm{NO}_{3}\right)$, phosphate $\left(\mathrm{PO}_{4}\right)$ and potassium (K) are largely consumed by plants (Oren et al., 2004). Studied lakes show relative low $\mathrm{NO}_{3}$ concentrations (Fig. 14; Table 2). Plot $\mathrm{K}$ vs $\mathrm{NO}_{3}$ and the vertical profile of potassium suggest this element in Flores Lakes is not affected by aquatic organism metabolisms. Although, data suggests there may exist a permanent input of nitrate in Negra and Funda Lakes. Figure 15 show the $\mathrm{NO}_{3}$ variation in depth suggesting that nitrate can be affect by organism metabolism along the water column. However, nitrate results are of a short, timescale, no phosphate data is available and sampling was made in the period when phytoplankton are more productive (summer) for further consideration.

\section{CONCLUSION}

The studied aquatic ecosystems at Flores Island are emplaced in volcanic craters associated with hydromagmatism (maars). Lakes show thermal water stratification in the summer due to water density variations. Despite the thermal stratification, lakes do not show marked chemical composition stratification. In general, the lake waters correspond to freshwater with low mineralization. The smaller mass lakes are $\mathrm{Na}-\mathrm{Cl}$ dominated, whereas the larger mass lakes show a $\mathrm{Ca}-\mathrm{HCO}_{3}$ chemical facies. Three major processes control the hydrogeochemical properties of the studied lakes: (1) the marine sea salt contribution due to atmospheric transportation and deposition that influence the water chemistry of all lakes and is the main process that control the chemistry of Rasa Lake; (2) the contamination of Comprida Lakes by mineral water; (3) the input of rock

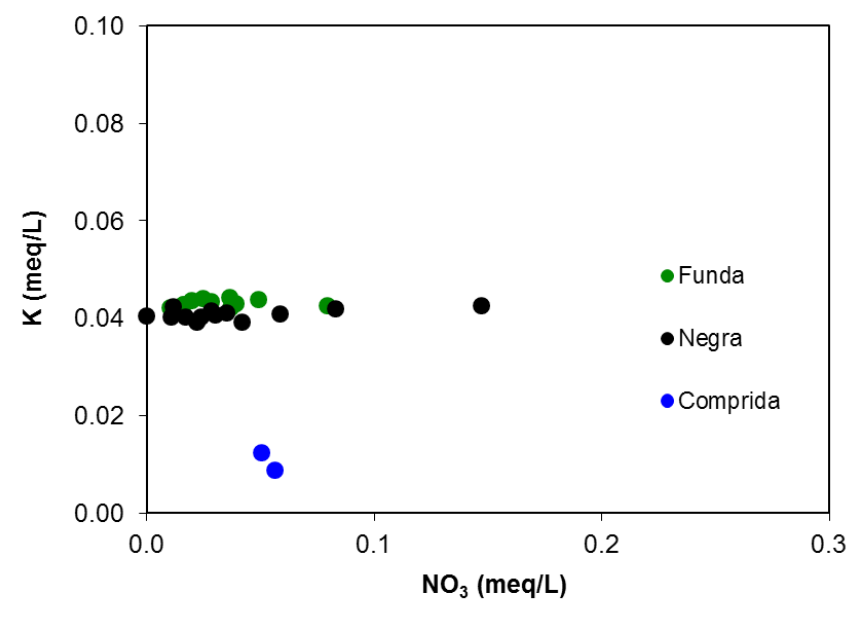

Figure 14. Variation of $\mathrm{K}$ compared to $\mathrm{NO}_{3}$ concentrations in the studied lakes.

Figura 14. Relação entre potassio e o nitrato nos lagos estudados. 


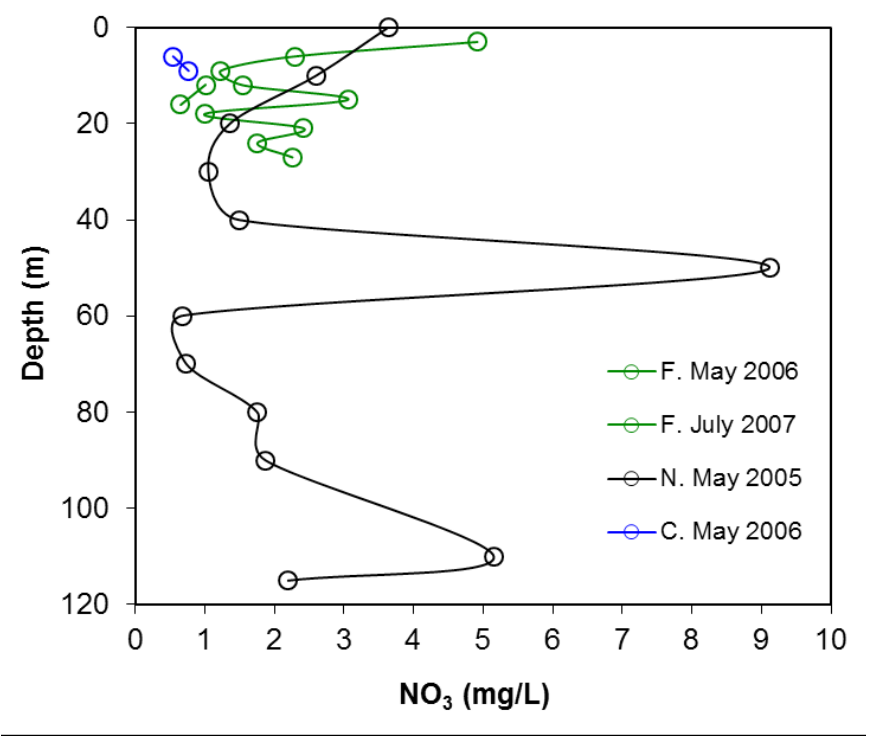

Figure 15. Vertical profiles showing the nitrate concentration variation in the studied lakes.

Figura 15. Resultado da concentraçâo do nitrato ao longo da coluna de água nos lagos estudados.

forming elements into the larger lakes as a result of weathering of rocks. Rock hydrolysis explains the more concentrated waters in Lakes Funda and Negra. All four lakes have no interaction with the seepage of magmatic fluids and the only source of $\mathrm{CO}_{2}$ is related to organic matter degradation that explains the low concentration of free $\mathrm{CO}_{2}$ in these aquatic systems. The concentrations of major chemical species in all of the studied lakes are well below the European Union standards and Portuguese law for drinking-water quality. The lake water quality degradation is related to anthropogenic influences with the input of artificial nutrients causing the increase in biological productivity.

More sampling campaigns are needed over the year to determine the thermal evolution, the spatial and temporal variation, the mixing properties of the lakes and analyze the artificial nutrient input related to groundwater and surface water interaction, mainly phosphate for further consideration related to safe water resources for drinking water. Further studies should consider the European Union environmental directives to reduce the impact of human activities on the aquatic environment, namely the Nitrates Directive, the Groundwater Directive and the Water Framework Directive to improve the planning and managing plans for protected areas in small islands.

\section{ACKNOWLEDGEMENTS}

We thank Lilly Corenthal for reviews comments greatly improved the clarity of the manuscript. The research for this paper was supported by a grant from Fundação para a Ciência e a Tecnologia (Portugal).

\section{REFERENCES}

Agostinho, J. (1938) - Clima dos Açores. Açoreana (ISSN: 0874-0380), 1(2):35-65, Angra do Heroísmo, Açores, Portugal. Available at http://www.azoresbioportal.angra. uac.pt/files/publicacoes_Agostinho38_ClimaDosAores.pdf

Aguiar, P.; Antunes, P.; Mestre, R.; Raposeiro, P. M.; Costa, A. (2008) - A Dinâmica Biogeoquímica de Sistemas Aquáticos da Ilha das Flores. In: João António Cândido Tavares \& Duarte Soares Furtado (Coord.), XIII Expedição Cientifica do Departamento de Biologia - Flores e Corvo 2007, Relatórios e Comunicaçóes do Departamento de Biologia, n.o 35, pp. 15-27, Universidade dos Açores, Ponta Delgada, Portugal. ISBN: 978-9728612382. Available at http://repositorio. uac.pt/bitstream/10400.3/708/1/Dinâmica\%20 biogeoqu \%C3\%ADmica\%20de\%20sistemas\%20 aquáticos\%20da\%20Ilha\%20das\%20Flores.pdf

Antunes, P. (2009) - Estudo hidrogeoquímico e vulcanológico de lagos no arquipélago dos Açores: aplicaçóes para a mitigação de riscos naturais. 306 p., Dissertação de Doutoramento, Universidade dos Açores, Ponta Delgada, Portugal. ISBN: 978-9728612795. Available at https://repositorio.uac. pt/handle/10400.3/1304

Antunes, P.; Rodrigues, F.C. (2011) - Azores Volcanic Lakes: factors affecting water quality. In: N. Peters, V. Krysanova, A. Lepisto, R. Prasad, M. Thoms, R. Wilby \& S. Zandaryaa (eds.), Water Quality: Currents Trends and Expected Climate Change Impacts, pp. 106-114, International Association of Hydrological Sciences, Wallingford, U.K. ISBN: 978-1907161230

Azevedo, E.M.V.B., (1996) - Modelação do clima Insular à escala local. 247p., Dissertação de Doutoramento, Universidade dos Açores, Angra do Heroísmo, Portugal. Unpublished.

Azevedo, J.M.M. (1998) - Geologia e Hidrogeologia da Ilha das Flores (Açores-Portugal). 403p., Dissertação de Doutoramento, Universidade de Coimbra, Coimbra, Portugal. Available at https://estudogeral.sib.uc.pt/ handle/10316/1892

Berner, E. K.; Berner, R. A. (1996) - Global Environment: Water, Air, and Geochemical Cycles. 444p., Prentice Hall, New Jersey, USA. ISBN: 0691136785" entre Azevedo, J.M.M. (1998) e Bettencout, M.L. (1979).

Bettencout, M.L. (1979) - O clima dos Açores como recurso natural, especialmente em agricultura e indistria do turismo. 104p., Instituto Nacional de Meteorologia e Geofísica, Lisboa, Portugal.

Brabec, E. (2002) - Impervious surfaces and water quality: a review of current literature and its implications for watershed planning. Journal of Planning Literature, 16(4):499-514. Available at http://works. bepress.com/elizabeth_brabec/11/

Carmichael, W.W. (2001) - Health effects of toxinproducing cyanobacteria: "The CyanoHABs". Human and Ecological Risk Assessment, 7(5):1393-1407. DOI: 10.1080/20018091095087

Christenson, B.W. (2000) - Geochemistry of fluids associated with the 1995-1996 eruption of Mt. 
Ruapehu, New Zealand: signatures and processes in the magmatic-hydrothermal system. Journal of Volcanology and Geothermal Research, 97(1-4):1-30. DOI: 10.1016/ S0377-0273(99)00167-5

Delmelle, P.; Bernar, A. (2000) - Volcanic lakes. In: H. Sigurdsson, S., McNutt:, H. Rymer, H. \& D. Six (org.), Encyclopedia of Volcanoes, pp. 877-895, Academic Press, San Diego, CA, U.S.A.

Deutsch, W.J. (1997) - Groundwater geochemistry: fundamentals and applications to contamination. 232p., CRC Press, New York, NY, USA.

DROTRH; IA (2001) - Plano Regional da Água Relatório Técnico - Versáo para Consulta Pública. 414p., Secretaria Regional do Ambiente, Direcção Regional do Ordenamento do Território e dos Recursos Hídricos, Ponta Delgada, Portugal. Available at http://portaldaagua.inag. pt/PT/InfoTecnica/PGA/PRPlaneamento/Documents/ relatorio_PRA.pdf

Ellwood, N. T. W.; Mosello, R.; Albertano, P. (2005) - A seasonal survey on the water quality and phytoplankton dynamics of Lake Albano. In: Convegni Lincei 218-Ecosistema Roma, pp. 209-262, Bardi Editore, Roma, Italy.

Forjaz, V.H. (1983) - Azores tectonic sketch. 1p., Centro de Vulcanologia, Universidade dos Açores, Ponta Delgada, Portugal. Unpublished.

Gonçalves, V. (1997) - Estrutura da Comunidade Fitoplanctónica da Lagoa das Furnas. 229p., Provas de Aptidão Pedagógica e Capacidade Científica, Departamento de Biologia, Universidade dos Açores, Ponta Delgada, Portugal. Unpublished.

Gonçalves, V. (2008) - Contribuição para o estudo da qualidade ecológica das lagoas dos Açores: Fitoplancton e diatomáceas bentónicas. 331p., Dissertaçáo de Doutoramento, Universidade dos Açores, Ponta Delgada, Portugal. Unpublished.

Gonçalves, V.; Costa, A.C.; Raposeiro, P.M.; Marques, H. (2005) - Caracterização biológica das massas de água superficiais das ilhas de São Miguel e Santa Maria. 164p., Centro de Conservação e Protecção do Ambiente, Universidade dos Açores, Ponta Delgada, Portugal.

Hockings, M.; Stolton, S.; Dudley, N. (2006) - Evaluating effectiveness: A framework for assessing the management of protected areas. 105p., IUCN (International Union for Conservation of Nature and Natural Resources), Gland, Switzerland / Cambridge, U.K. ISBN-13: 9782831709390. Available on-line at https://portals.iucn. org/library/efiles/edocs/PAG-014.pdf

Hockings, M. (2003) - Systems for assessing the effectiveness of management in Protected Areas. BioScience, 53(9):823832. DOI:10.1641/0006-3568(2003)053[0823:SFATEO]2.0.CO;2

INOVA (1999) - Análise das Águas das Lagoas da Região Autónoma dos Açores. 291p., INOVA (Instituto de Inovação Tecnológica dos Açores), Ponta Delgada, Portugal. Unpublished.

Karr, J.R. (1993) - Defining and assessing ecological integrity: Beyond water quality. Environmental Toxicology and Chemistry, 12(9):1521-1531. DOI: 10.1002/ etc. 5620120902
Krause, D.; Watkings, N. (1970) - North Atlantic crustal genesis in the vicinity of the Azores. Geophysical Journal International, 19(3):261-283. DOI: 10.1111/j.1365246X.1970.tb06046.x

Lampert, W.; Sommer, U. (2007) - Limnoecology: the ecology of Lakes and streams. 324p., Oxford University Press, Oxford, England, U.K.

Laughton, A. S.; Whitmarsh, R. B. (1974) - The AzoresGibraltar plate boundary. In: Geodynamics of Iceland and the North Atlantic area, pp. 63-81, Springer Netherlands, Dordrecht, Netherlands.

Lourenço, N.; Miranda, J.M.; Luis, J.F.; Ribeiro, A.; Victor, L.A.M.; Madeira, J.; Needham, H.D., (1998) - Morpho-tectonic analysis of the Azores Volcanic Plateau from a new bathymetric compilation of the area. Marine Geophysical Researches, 20(3):141-156. DOI: 10.1023/A: 1004505401547

Miranda, P.M.A.; Valente, M.A.; Tomé, A.R.; Trigo, R.; Coelho, M.F.E.S.; Aguiar, A.; Azevedo, E.B. (2006) - O clima de Portugal nos Séculos XX e XXI. In: F. D. Santos \& P. Miranda (org.), Alteraçóes climáticas em Portugal Cenários, impactos e medidas de adaptação, Ed. Gradiva, Lisboa, Portugal. Available at http://siam.fc.ul.pt/ siamII_pdf/SIAMII.pdf

Morrisseau, M. (1987) - Les éruptions hydromagmatiques et les xenolites associes: signification geothermique (exemples de Flores et de Faial, Açores). 487p., Thèse de Doctorat, Université de Paris 11, Paris, France.

Moyle, P.B.; Randall, P.J. (1998) - Evaluating the Biotic Integrity of Watersheds in the Sierra Nevada, California. Conservation Biology, 12(6):1318-1326. DOI: 10.1111/j.1523-1739.1998.97161.x

Oren, O.; Yechieli, Y.; Bohlke, J.K.; Dody, A. (2004) Contamination of groundwater under cultivated fields in an arid environment, central Arava Valley, Israel. Journal of Hydrology, 290(3-4):312-328. DOI: 10.1016/j. jhydrol.2003.12.016

Porteiro, J. (2000) - Lagoas dos Açores: elementos de suporte ao planeamento integrado. 344 p., Dissertação de Doutoramento, Universidade dos Açores, Ponta Delgada, Portugal. Unpublished.

Rowe Jr, G.L.; Brantley, S.L; Fernandez, M.; Fernandez, Borgia, A.; Barquero, J.; (1992) - Fluid-volcano interaction in an active stratovolcano: the crater lake system of Poás volcano, Costa Rica. Journal of Volcanology and Geothermal Research, 49(1-2):23-51. DOI: 10.1016/0377-0273(92)90003-V

Saunders, D.L.; Meeuwig, J.J.; Vincent, A.C.J. (2002) - Freshwater Protected Areas: Strategies for Conservation. Conservation Biology, 16(1):30-41. DOI: 10.1046/j.1523-1739.2002.99562.x

Searle, R. (1980) - Tectonic pattern of the Azores spreading centre and triple junction. Earth and Planetary Science Letters, 51(2):415-434. DOI: 10.1016/0012821X(80)90221-6

Simeonov, V.; Stratis, J.A.; Samara, C.; Zachariadis, G.; Voutsa, D.; Anthemidis, A.; Sofoniou, M.; Kouimtzis, T. (2003) - Assessment of the surface water quality in Northern Greece. Water Research, 37(17):4119-4124. DOI: $10.1016 /$ S0043-1354(03)00398-1 
Steinmetz, L.; Hirn, A.; Sapin, M.; Whitmarsh, R.; Moreira, V. (1976) - Zones of $P$ wave attenuation beneath the crest of Mid-Atlantic Ridge. Bulletin de la Société Géologique de France, V. Series 7, XVIII(4):931-936. DOI: 10.2113/ gssgfbull.S7-XVIII.4.931

UNL (1991) - O controle da eutrofização nas lagoas de S. Miguel - Açores. DCEA/FCT, Universidade Nova de Lisboa, Lisboa, Portugal. Unpublished.

Varekamp, J.C. (2008) - The volcanic acidification of glacial Lake Cavihue, Province of Neuquen, Argentina. Journal of Volcanology and Geothermal Research, 178(2):184-196. DOI: 10.1016/j.jvolgeores.2008.06.016
Varekamp, J.C.; Pasternack, G.B.; Rowe Jr.; G.L. (2000) - Volcanic lake systematics II. Chemical constraints. Journal of Volcanology and Geothermal Research, 97(14):161-179. DOI: 10.1016/S0377-0273(99)00182-1

Wetzel, R.G. (1993) - Limnologia. 919p., Fundação Calouste Gulbenkian, Lisboa, Portugal. ISBN: 0030579139.

Wilson, N. (1995) - Soil water and groundwater sampling. 188p., CRC Press, New York, NY, USA. ISBN: 1-56670073-6. 